\title{
Hemoglobinopathies (Sickle Cell Disease and Thalassemia)
}

\author{
Barbara Cappelli, Eliane Gluckman, \\ Khaled Ghanem, and Miguel R. Abboud
}

\subsection{HSCT for Sickle Cell Disease}

Barbara Cappelli and Eliane Gluckman

\subsubsection{Definition and Epidemiology}

Sickle cell disease (SCD) is the most common inherited hemoglobinopathy worldwide. It results from a single-nucleotide substitution that leads to a propensity toward hemoglobin polymerization and sickling of red blood cells. Sickle cell disease is characterized by anemia, ongoing hemolysis, and acute and chronic vaso-occlusive complications affecting multiple organs. SCD affects over

B. Cappelli

Eurocord-Monacord, Centre Scientifique de Monaco, Monaco, Monaco

E. Gluckman $(\bowtie)$

Eurocord, Department of Hematology, Hospital Saint Louis, University Paris-Diderot, Paris, France

e-mail: eliane.gluckman@ aphp.fr

K. Ghanem

BASMA Pediatric Oncology Unit,

Al Bairouni Hospital, Damascus, Syria

M. R.Abboud

Department of Pediatrics and Adolescent Medicine, American University of Beirut Medical Center,

Beirut, Lebanon
100,000 Americans, and it occurs in about one in 500 African-American births and in one in every 1000-1400 Hispanic-American births (NIH 2014; Piel et al. 2013).

The implementation of newborn screening, penicillin prophylaxis, vaccination programs, narcotics, chronic transfusions, hydroxyurea, and the early detection of cerebral vasculopathy with transcranial Doppler (TCD) have improved the perspective for children with SCD (Angelucci et al. 2014; Yawn et al. 2014; Ware et al. 2016; Bernaudin et al. 2016).

\subsubsection{Allo-HSCT with an HLA Identical Sibling}

HSCT remains the only curative therapy for SCD (Angelucci et al. 2014; Arnold et al. 2016; Gluckman et al. 2017). The goal when performing HSCT is to replace the patient's marrow with genetic functional cells before major organ dysfunction and complications (Bernaudin et al. 2007). Some of the most common indications for HSCT are listed in Table 79.1 (Angelucci et al. 2014; Bernaudin et al. 2016). 
Several barriers prevent HSCT widespread application including lack of a suitable donor, lack of information, and limited understanding of HSCT. Moreover, HSCT encompasses a risk of early- and late-onset regimen-related toxicities, rejection, and mortality. Nevertheless, the annual

Table 79.1 Indications for HSCT in SCD patients

\begin{tabular}{|c|c|}
\hline Age $<16$ years & \\
\hline $\begin{array}{l}\text { HLA identical } \\
\text { sibling donor }\end{array}$ & \\
\hline $\begin{array}{l}\text { One or more of the } \\
\text { following }\end{array}$ & $\begin{array}{l}\text { Stroke or central nervous system } \\
\text { event lasting }>24 \mathrm{~h}\end{array}$ \\
\hline complications: & Sickle lung disease \\
\hline & Sickle nephropathy \\
\hline & Retinopathy \\
\hline & Osteonecrosis \\
\hline & Red-cell alloimmunization \\
\hline & Acute chest syndrome \\
\hline & Recurrent priapism \\
\hline & $\begin{array}{l}\text { Recurrent vaso-occlusive painful } \\
\text { episodes }\end{array}$ \\
\hline & $\begin{array}{l}\text { Failure to benefit or unable or } \\
\text { unwilling to continue supportive } \\
\text { care therapy including hydroxyurea }\end{array}$ \\
\hline & $\begin{array}{l}\text { Impaired neuropsychological } \\
\text { function with abnormal cerebral } \\
\text { MRI and angiography }\end{array}$ \\
\hline & $\begin{array}{l}\text { Abnormal transcranial Doppler } \\
\text { velocities }\end{array}$ \\
\hline
\end{tabular}

Modified from (Angelucci et al. 2014) number of transplants have been increasing and has quadrupled in the last decade (CIBMTR personal communication). The first successful HLA identical HSCT was performed in a patient affected by both SCD and AML in 1984 (Johnson et al. 1984). After that, many groups have described a series of patients transplanted from an HLA identical sibling with an OS that varies between 91 and $100 \%$ and EFS that varies between 73 and 100\% (Bernaudin et al. 2007; Walters et al. 2016). Recently, 1000 HLA identical transplants, performed between 1986 and 2013 and reported to EBMT, Eurocord, and the CIBMTR, have been published with a 5-year EFS and OS of $91.4 \%$ (95\% CI 89.6-93.3\%) and 92.9\% (95\% CI 91.1$94.6 \%$ ), respectively. The EFS and OS were both lower with increasing age, EFS was higher for transplantations performed after 2006, and OS was lower for peripheral blood transplant recipients (Fig. 79.1) (Gluckman et al. 2017).

\subsubsection{Indications}

Indication for HSCT for "less severe patients" before significant organ damage has occurred is open to discussion. In fact, on one hand, it would be better to transplant them early in order to pre-
Fig. 79.1 Overall survival according to stem cell source on 1000 SCD patients transplanted from an HLA identical sibling (Gluckman et al. 2017)

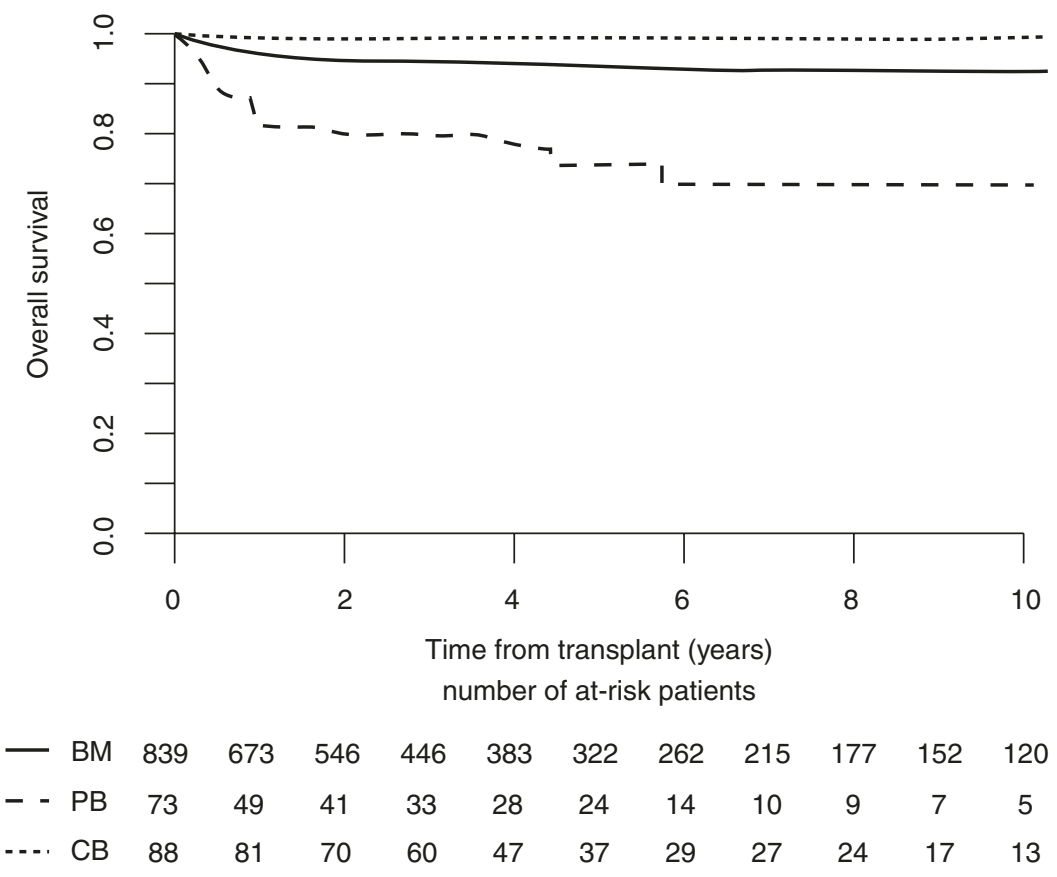


vent early organ damage secondary to $\mathrm{SCD}$, avoid SCD complications in childhood, and achieve better HSCT outcomes secondary to less pre-HSCT organ damage and alloimmunization and, on the other hand, it could be considered to wait to perform an HSCT for the establishment of new available SCD supportive cares (new medications other than hydroxyurea), promising curative therapies (gene therapy), and advances in HSCT technology, others may be available. Nevertheless, it has been demonstrated that patients transplanted at a young age have a better 3-year OS and 3-year EFS, with lower incidence of aGvHD and cGvHD (Gluckman et al. 2017). These findings outline the importance of early referral to HSCT for SCD patients.

\subsubsection{Conditioning}

To date, a myeloablative conditioning regimen (especially with BU/CY + ATG) is the gold standard for HLA identical sibling HSCTs (EFS: 73-96\%, OS: 91-100\%) despite the risk of longterm transplant-related toxicity (Bernaudin et al. 2007; Walters et al. 2016). A conditioning regimen including FLU and BU has been used but with high GvHD risk; therefore, it should be considered to add ATG to the conditioning regimen to lower the GvHD risk in these patients.

A RIC regimen has been explored to decrease toxicity and allow a stable, mixed chimerism. The aim of a tailored conditioning regimen in children is to preserve fertility, whereas in adults is to reduce toxicity in severely compromised patients due to their underlying disease. Several reduced intensity conditioning regimens (FLU/ MEL + ALEM +/- TT or ALEM + TBI 300 cGy +/- PT-CY or FLU/CY or TBI $300 \mathrm{cGy} \mathrm{+/-}$ ATG) have been used in many small patient series but with high degree of graft rejection (Talano and Cairo 2015; Arnold et al. 2016). Thus, recently, encouraging outcomes and low earlyand long-term toxicity have been confirmed by other groups after FLU-based RIC regimens (Bhatia et al. 2014). Lately, 13 high-risk patients conditioned with a chemotherapy-free regimen
(ALEM-TBI 300 cGy) have shown a 92\% DFS and $100 \%$ OS (Saraf et al. 2016).

Moreover, a prospective multicenter trial comparing allogeneic matched related HSCT after a RIC regimen, with standard of care in adolescents and adults with severe SCD, has shown encouraging preliminary results (Dhedin et al. 2016).

Despite MAC dosing in the conditioning regimens, a mixture of both donor and recipient hematopoietic cells (mixed donor chimerism) can be consistently observed in approximately 10-20\% of these children (Bernaudin et al. 2007; Walters et al. 2016). Interestingly, this mixed chimeric state with the presence of both recipient and donor blood cells is sufficient to direct bone marrow to preferentially produce donortype hemoglobin (rather than abnormal hemoglobin of the recipient), and red cells revert the SCD phenotype, and minimize the risk of GVHD, confirming the therapeutic efficacy of mixed chimerism for hemoglobinopathies. New studies on mixed chimerism are ongoing.

\subsubsection{Alternative Donors}

Finding a potential MUD is based on the ethnic and racial background; for SCD patients the probability for an 8/8 HLA MUD or CB donor is less than $18 \%$. Nevertheless, some small series of patients using URD have been published, but for now relapse rate and GvHD risk remain unacceptable (Justus et al. 2015).

Strategies that explore the use of mismatched related (haplo) donors are ongoing (Dallas et al. 2013; Talano and Cairo 2015). Recently promising results of $\mathrm{CD} 3+/ \mathrm{CD} 19+$ depleted T-cell haplo-HSCT after TREO/FLU/TT + ATG have been shown to be safe and efficient with a low incidence of GvHD in advanced stage SCD (Foell et al. 2017).

Moreover, new strategies using gene therapy have been recently published with encouraging results (Ribeil et al. 2017), and the use of gene editing is being explored for this single-mutation disease (Canver and Orkin 2016). 


\subsection{Thalassemia}

Khaled Ghanem and Miguel R. Abboud

\subsubsection{Introduction}

The outcome of thalassemia major (TM, transfusion-dependent thalassemia) has improved dramatically over the past two decades due to improvements in supportive care and iron chelation therapy (Taher et al. 2018). Life expectancy for TM patients exceeds 40 years, and it is no longer significantly different from the life expectancy of thalassemia intermedia patients, in developed countries (Vitrano et al. 2017).

Match family donor (MFD) allo-HSCT is currently considered the only curative standard therapeutic approach for TM, which despite holding its own risks, could release the patient from lifelong treatments, and possible iron accumulation complications. Despite encouraging results of gene therapy, its use is currently limited to clinical trials.

\subsubsection{Best Transplant Candidates}

In late 1990s, the Pesaro group has proposed a risk classification for pediatric patients undergoing MFD HSCT for TM (Lucarelli et al. 1998). The classification depended on three risk factors (Table 79.2) and was validated in the pediatric population; however, it did not predict risk in adult patients (Angelucci et al. 2017). Limitations to this risk stratification include the interobserver variability regarding hepatomegaly and the lack of clear definition of adequate iron chelation. The

Table 79.2 Pesaro classifications for risk assessment prior to HSCT for TM (Lucarelli et al. 1998)

\begin{tabular}{|c|c|c|c|}
\hline Risk factor & $\begin{array}{l}\text { Class } \\
1\end{array}$ & $\begin{array}{l}\text { Class } 2 \text { (min. 1, } \\
\max .2)\end{array}$ & $\begin{array}{l}\text { Class } \\
3\end{array}$ \\
\hline $\begin{array}{l}\text { Inadequate } \\
\text { chelation }\end{array}$ & $x$ & $\times / \sqrt{ }$ & $\checkmark$ \\
\hline $\begin{array}{l}\text { Hepatomegaly } \\
>2 \mathrm{~cm}\end{array}$ & $x$ & $\times / \sqrt{ }$ & $\checkmark$ \\
\hline Portal fibrosis & $x$ & $\times / \sqrt{ }$ & $\checkmark$ \\
\hline
\end{tabular}

Pesaro classification is applicable in the setting of best medical care. In developing countries, where medical care might not be optimal, a very-highrisk group was identified in Pesaro class 3 patients if liver size is $>5 \mathrm{~cm}$ below the costal margin and if the patient age is $>7$ years (Mathews et al. 2007). The EBMT has recently identified the age of 14 years as the oldest age for optimal outcome in MFD HSCT for TM (Baronciani et al. 2016).

Accurate assessment of iron content in the liver and heart is crucial before proceeding to transplant. No consensus is currently available regarding the best method of iron content assessment in both organs. Serum ferritin level might not reflect accurately the severity of iron overload. Liver biopsy is the gold standard; however, it carries the risks of the invasive procedure. Transient elastography (FibroScan) and T2 MRI have been shown to be reliable noninvasive methods to predict liver fibrosis secondary to iron overload, for TM patients who are candidates to HSCT (Hamidieh et al. 2014; Hamidieh et al. 2015).

\subsubsection{Conditioning Regimens}

The use of the myeloablative BU and CY as the conditioning regimen for HSCT for TM has been the standard practice, due to the increased marrow activity and the allo-sensitization in heavily transfused patients (Lucarelli et al. 1990). However, this regimen was associated with hepatic and cardiac toxicity due to the iron overload and the toxic hepatic and cardiac effects of $\mathrm{BU}$ and CY, respectively.

ATG or ALEM have been added in some protocols to the conditioning regimen to prevent GvHD and enhance engraftment (Law et al. 2012; Mohty 2012). Despite being effective with low incidence of infections, the use of these agents is still debatable.

In an attempt to reduce the extramedullary toxicity of BU and CY, a non-myeloablative regimen of TREO/FLU/TT has been used with encouraging results (Bernardo et al. 2012). Defibrotide has been used successfully to prevent SOS/VOD in patients with TM undergoing 
HSCT with conditioning regimen containing IV BU (Cappelli et al. 2009). The use of BU pharmacokinetics was associated with better engraftment and less toxicity (Gaziev et al. 2010); however, these studies are available in limited number of institutions worldwide.

\subsubsection{Alternative Donors}

\subsubsection{Matched Unrelated Donors (MUD)}

In case MFD is not available, the discovery of high-resolution HLA typing techniques made the performance of successful MUD transplant possible. The probability of finding a matched unrelated donor varies between $50 \%$ in Caucasians to less than $10 \%$ in some minorities (Rocha and Locatelli 2008). With the use of BU, CY, TT, and FLU as conditioning regimen and ATG, MMF, and short-course MTX as GvHD prophylaxis, the outcome of PBSC MUD in TM was comparable to MFD HSCT in regard to OS, TRM, TFS, and aGvHD (Li et al. 2012).

\subsubsection{Unrelated Umbilical Cord}

The use of unrelated umbilical cord as a source of stem cells for HSCT in TM is hampered by the high incidence of graft failure due to the low stem cell dose. The graft failure rate could be as high as $57 \%$ (Ruggeri et al. 2011). This could be partially overcome by the use of double UCB units. The 5-year overall and thalassemia-free survival rates were 88.3 and $73.9 \%$, respectively, when using two units instead of one if no single units included more than $25 \times 10^{6}$ total nucleated cells/ $\mathrm{kg}$ of recipient weight. Other strategies to overcome the main barrier of low cell dose include co-transplantation of third-party mesenchymal stromal or TCD haploidentical cells (Kwon et al. 2014; Kim et al. 2004).

\subsubsection{Haploidentical HSCT}

Due to the low probability of finding a MUD in some ethnicities and the previously mentioned issues with umbilical-cord transplant, new strategies have been evolved to develop an effective and safe haploidentical transplant procedure for TM patients. The use of TCD graft was associated with high rate of infections and increased risk of graft failure due to allo-sensitization and hyperactive marrow (Gaziev et al. 2000). This was overcome by pretransplant over-transfusion and immunosuppressive therapy and post transplant infusion of transduced donor T-cells with geneinducible caspase-9 (Bertaina et al. 2017). The use of T-cell replete grafts is still under investigation to explore the best strategy to prevent GvHD.

\subsubsection{Mixed Chimerism}

The incidence of mixed chimerism after HSCT for TM was reported to be around $12 \%$. the risk of graft rejection in patients with mixed chimerism was high only if mixed chimerism had been observed within two months post-transplant. Most cases with late persistent mixed chimerism evolved into either stable chimerism or complete engraftment and did not require additional PRBC transfusion support (Andreani et al. 2000).

\subsubsection{Post transplant Iron Chelation}

Iron overload remains a problem after HSCT, and most investigators rely on phlebotomy to decrease excessive iron stores. In a recent phase II, multicenter, single-arm trial, deferasirox at a dose of $20 \mathrm{mg} / \mathrm{kg} /$ day, starting after a minimum of 6 months of transplant, and continued for 1 year, was safe and associated with decreased burden of iron overload after transplant (serum ferritin, liver, and cardiac iron content by MRI) (Yesilipek et al. 2018). 


\section{Key Points}

- HLA identical sibling HSCT is an established treatment option for SCD.

- HSCT should be performed as early as possible, preferably at pre-school age, and BU, CY, and ATG should be used as conditioning regimen.

- Match family donor allo-HSCT is currently considered the only curative standard therapeutic approach for thalassemia major, which despite holding its own risks, could release the patient from lifelong treatments and possible iron accumulation complications.

- Despite encouraging results of gene therapy, its use in TM is currently limited to clinical trials.

\section{References}

Andreani M, Nesci S, Lucarelli G, et al. Long-term survival of ex-thalassemic patients with persistent mixed chimerism after bone marrow transplantation. Bone Marrow Transplant. 2000;25:401-4.

Angelucci E, Matthes-Martin S, Baronciani D, et al. EBMT Inborn Error and EBMT Paediatric Working Parties. Hematopoietic stem cell transplantation in thalassemia major and sickle cell disease: indications and management recommendations from an international expert panel. Haematologica. 2014;99:811-20.

Angelucci E, Pilo F, Coates TD. Transplantation in thalassemia: Revisiting the Pesaro risk factors 25 years later. Am J Hematol. 2017;92:411-3.

Arnold SD, Bhatia M, Horan J, Krishnamurti L. Haematopoietic stem cell transplantation for sickle cell disease - current practice and new approaches. $\mathrm{Br}$ J Haematol. 2016;174:515-25.

Baronciani D, Angelucci E, Potschger U, et al. Hemopoietic stem cell transplantation in thalassemia: a report from the European Society for Blood and Bone Marrow Transplantation Hemoglobinopathy Registry, 20002010. Bone Marrow Transplant. 2016;51:536-41.

Bernardo ME, Piras E, Vacca A, et al. Allogeneic hematopoietic stem cell transplantation in thalassemia major: results of a reduced-toxicity conditioning regimen based on the use of treosulfan. Blood. 2012;120:473-6.

Bernaudin F, Socie G, Kuentz M, et al. SFGM-TC. Longterm results of related myeloablative stemcell transplantation to cure sickle cell disease. Blood. 2007;110:2749-56.

Bernaudin F, Verlhac S, Arnaud C, et al. Long-term treatment follow-up of children with sickle cell disease monitored with abnormal transcranial Doppler velocities. Blood. 2016;127:1814-22.

Bertaina A, Pitisci A, Sinibaldi M, Algeri M. T CellDepleted and T Cell-Replete HLA-Haploidentical Stem Cell Transplantation for Non-malignant Disorders. Curr Hematol Malig Rep. 2017;12:68-78.

Bhatia M, Jin Z, Baker C, et al. Reduced toxicity, myeloablative conditioning with BU, fludarabine, alemtuzumab and SCT from sibling donors in children with sickle cell disease. Bone Marrow Transplant. 2014;49:913-20.

Canver MC, Orkin SH. Customizing the genome as therapy for the beta-hemoglobinopathies. Blood. 2016;127:2536-45.

Cappelli B, Chiesa R, Evangelio C, et al. Absence of VOD in paediatric thalassaemic HSCT recipients using defibrotide prophylaxis and intravenous Busulphan. $\mathrm{Br}$ J Haematol. 2009;147:554-60.

Dallas MH, Triplett B, Shook DR, et al. Long-term outcome and evaluation of organ function in pediatric patients undergoing haploidentical and matched related hematopoietic cell transplantation for sickle cell disease. Biol Blood Marrow Transplant. 2013;19:820-30.

Dhedin N, de la Fuente J, Bernaudin F, et al. Haploidentical Bone Marrow Transplant with Post-Transplant Cytoxan Plus Thiotepa Improves Donor Engraftment in Patients with Sickle Cell Anemia: Results of an International Multicenter Learning Collaborative Trial. Blood. 2016;128:1233. (ASH Abstract).

Foell J, Pfirstinger B, Rehe K, et al. Haploidentical stem cell transplantation with CD3(+)-/CD19(+)- depleted peripheral stem cells for patients with advanced stage sickle cell disease and no alternative donor: results of a pilot study. Bone Marrow Transplant. 2017;52:938-40.

Gaziev D, Galimberti M, Lucarelli G, et al. Bone marrow transplantation from alternative donors for thalassemia: HLA-phenotypically identical relative and HLA-nonidentical sibling or parent transplants. Bone Marrow Transplant. 2000;25:815-21.

Gaziev J, Nguyen L, Puozzo C, et al. Novel pharmacokinetic behavior of intravenous busulfan in children with thalassemia undergoing hematopoietic stem cell transplantation: a prospective evaluation of pharmacokinetic and pharmacodynamic profile with therapeutic drug monitoring. Blood. 2010;115:4597-604.

Gluckman E, Cappelli B, Bernaudin F, et al. Sickle cell disease: an international survey of results of HLAidentical sibling hematopoietic stem cell transplantation. Blood. 2017;129:1548-56.

Hamidieh AA, Moeininia F, Tayebi S, et al. Efficacy of hepatic T2* MRI values and serum ferritin concentration in predicting thalassemia major classification for hematopoietic stem cell transplantation. Pediatr Transplant. 2015;19:301-6.

Hamidieh AA, Shazad B, Ostovaneh MR, et al. Noninvasive measurement of liver fibrosis using transient elastography in pediatric patients with major thalassemia who are candidates for hematopoietic stem cell transplantation. Biol Blood Marrow Transplant. 2014;20:1912-7. 
Johnson FL, Look AT, Gockerman J, et al. Bone-marrow transplantation in a patient with sickle-cell anemia. N Engl J Med. 1984;311:780-3.

Justus D, Perez-Albuerne E, Dioguardi J, et al. Allogeneic donor availability for hematopoietic stem cell transplantation in children with sickle cell disease. Pediatr Blood Cancer. 2015;62:1285-7.

Kim DW, Chung YJ, Kim TG, et al. Cotransplantation of third-party mesenchymal stromal cells can alleviate single-donor predominance and increase engraftment from double cord transplantation. Blood. 2004;103:1941-8.

Kwon M, Bautista G, Balsalobre P, et al. Haplo-cord transplantation using CD34+ cells from a third-party donor to speed engraftment in high-risk patients with hematologic disorders. Biol Blood Marrow Transplant. 2014;20:2015-22.

Law J, Cowan MJ, Dvorak CC, et al. Busulfan, fludarabine, and alemtuzumab as a reduced toxicity regimen for children with malignant and nonmalignant diseases improves engraftment and graft-versus-host disease without delaying immune reconstitution. Biol Blood Marrow Transplant. 2012;18:1656-63.

Li C, Wu X, Feng X, et al. A novel conditioning regimen improves outcomes in beta-thalassemia major patients using unrelated donor peripheral blood stem cell transplantation. Blood. 2012;120:3875-81.

Lucarelli G, Galimberti M, Giardini C, et al. Bone marrow transplantation in thalassemia. The experience of Pesaro. Ann N Y Acad Sci. 1998;850:270-5.

Lucarelli G, Galimberti M, Polchi P, et al. Bone marrow transplantation in patients with thalassemia. $\mathrm{N}$ Engl J Med. 1990;322:417-21.

Mathews V, George B, Deotare U, et al. A new stratification strategy that identifies a subset of class III patients with an adverse prognosis among children with beta thalassemia major undergoing a matched related allogeneic stem cell transplantation. Biol Blood Marrow Transplant. 2007;13:889-94.

Mohty M. A bit of antithymocyte globulin can take you a long way! Bone Marrow Transplant. 2012;47:617-8.

National Heart, Lung, and Blood Institute. Evidencebased management of sickle cell disease. Expert Panel Report. Bethesda: National Heart, Lung, and Blood Institute; 2014. https://www.nhlbi.nih.gov/sites/www. nhlbi.nih.gov/files/sicklecell-disease-report.pdf.

Piel FB, Hay SI, Gupta S, et al. Global burden of sickle cell anaemia in children under five, 2010-2050: mod- elling based on demographics, excess mortality, and interventions. PLoS Med. 2013;10:e1001484.

Ribeil JA, Hacein-Bey-Abina S, Payen E, et al. Gene Therapy in a Patient with Sickle Cell Disease. N Engl J Med. 2017;376:848-55.

Rocha V, Locatelli F. Searching for alternative hematopoietic stem cell donors for pediatric patients. Bone Marrow Transplant. 2008;41:207-14.

Ruggeri A, Eapen M, Scaravadou A, et al. Umbilical cord blood transplantation for children with thalassemia and sickle cell disease. Biol Blood Marrow Transplant. 2011;17:1375-82.

Saraf SL, Oh AL, Patel PR, et al. Nonmyeloablative Stem Cell Transplantation with Alemtuzumab/Low-Dose Irradiation to Cure and Improve the Quality of Life of Adults with Sickle Cell Disease. Biol Blood Marrow Transplant. 2016;22:441-8.

Taher AT, Weatherall DJ, Cappellini MD. Thalassaemia. Lancet. 2018;391:155-67.

Talano JA, Cairo MS. Hematopoietic stem cell transplantation for sickle cell disease: state of the science. Eur J Haematol. 2015;94:391-9.

Vitrano A, Calvaruso G, Lai E, et al. The era of comparable life expectancy between thalassaemia major and intermedia: Is it time to revisit the major-intermedia dichotomy? Br J Haematol. 2017;176:124-30.

Walters MC, De Castro LM, Sullivan KM, et al. Indications and results of HLA-identical sibling hematopoietic cell transplantation for sickle cell disease. Biol Blood Marrow Transplant. 2016;22:207-11.

Ware RE, Davis BR, Schultz WH, et al. Hydroxycarbamide versus chronic transfusion for maintenance of transcranial doppler flow velocities in children with sickle cell anaemia-TCD With Transfusions Changing to Hydroxyurea (TWiTCH): a multicentre, open-label, phase 3, non-inferiority trial. Lancet. 2016;387:661-70.

Yawn BP, Buchanan GR, Afenyi-Annan AN, et al. Management of sickle cell disease: summary of the 2014 evidence-based report by expert panel members. JAMA. 2014;312:1033-48.

Yesilipek MA, Karasu G, Kaya Z, et al. A Phase II, Multicenter, Single-Arm Study to Evaluate the Safety and Efficacy of Deferasirox after Hematopoietic Stem Cell Transplantation in Children with betaThalassemia Major. Biol Blood Marrow Transplant. 2018;24:613-8.

Open Access This chapter is licensed under the terms of the Creative Commons Attribution 4.0 International License (http://creativecommons.org/licenses/by/4.0/), which permits use, sharing, adaptation, distribution and reproduction in any medium or format, as long as you give appropriate credit to the original author(s) and the source, provide a link to the Creative Commons license and indicate if changes were made.

The images or other third party material in this chapter are included in the chapter's Creative Commons license, unless indicated otherwise in a credit line to the material. If material is not included in the chapter's Creative Commons license and your intended use is not permitted by statutory regulation or exceeds the permitted use, you will need to obtain permission directly from the copyright holder.

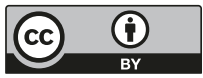

